\title{
Gender Stereotyping through Textbook Illustrations: A Case Study of Algerian Middle School Textbook- Spotlight on English 1
}

\author{
Dr. Bakhta Abdelhay \\ Wassila Benhaddouche \\ Department of English, Faculty of Foreign Languages University of Mostaganem, Algeria \\ Bakhta.abdelhay@gmail.com
}

\section{Doi:10.5901/mjss.2015.v6n5p435}

\section{Abstract}

Research confirms that combining texts and illustrations in teaching materials, enhances learners' achievements. However, many educators, authors and textbooks' analysts may not share this claim. For them, the idea that the textbooks, in general and the textbook illustrations in particular have a positive/negative impact on EFL learners' outcomes has not been thoroughly examined. Therefore, this study provides empirical evidence regarding the side-effects of the use of textbooks' illustrations and their influence on EFL learners' attitudes from a hidden curriculum perspective. More specifically, this study is designed to determine if gender is portrayed in Spotlight on English1, a textbook of first year Middle School, in a neutral and impartial way. The sample of the study consists then of the above mentioned textbook currently in use and a number of pupils estimated as approximately 23 boys and 23 girls. To collect data, the textbook illustrations where male and female characters are shown, are content analyzed. To know how women and men are depicted, a set of well-defined variables are put forward. They include productive versus reproductive occupations, sport activities, and frequency of appearances. The results show that males' illustrations outnumber the females' picture representations. In addition, women were portrayed more often, in stereotypical activities that reinforce the traditional image of them in society such as being a teacher, secretary, type-writer, and top-model. Men were depicted in more outdoor, adventurous, and skilful activities such as being a doctor, journalist, veterinarian, and actor, among other occupations. Physical education and sport games are also depicted as a male-domain. It is also important to stress that, such a preconceived allocation of roles, attitudes and actions reduces the girls' future prospects in their lives as well as boys' attitudes and knowledge about people and how do they relate to each other

Keywords: Gender bias, textbook illustrations, content analysis method

\section{Introduction}

Although research in the field of gender studies has certainly developed for the last decade, very few has been done so as to explain how textbook illustrations have impacted on the teaching and learning of English language. More importantly is the case of EFL contexts, notably in the Algerian schools. Therefore, the present work offers an opportunity to reflect critically upon the distribution of gender roles in a series of middle school textbooks' pictorial illustrations and see to what extent do they duplicate society's deep-seated stereotypes. More than that, one of the primary goals is to find out if they contribute to their continuation and to figure out what ideas and values do the people of both sexes stand for. Furthermore, among the set objectives of this research is to determine gender bias, and to see whether the pictorial contents used in our textbooks are sexist and discriminatory against women or are they rather neutral and represent the two sexes in an impartial and fair manner. Such an attempt aims to carry out an evaluation that would be fruitful in raising gender-sensitive awareness among teachers as well as learners and to turn their gaze towards the under searched gender stereotyped issues

Our hypotheses, firstly, presuppose that the EFL textbook currently in use in Algerian middle schools as designed after the 2005 reform is biased against women. Secondly, the illustrations represent carbon copies of society's cultural stereotypes and share even the responsibility of their continuation in reality. In this connection, it seems advisable not to belittle the importance of the visual mode of learning apart from the textual information found in the textbooks. We finally hypothesize, that gender bias transmitted through the textbook Illustrations has negative impacts on the learners' construction of identities and perceptions

To falsify or corroborate our three hypotheses, we have raised three questions, which are meant to probe deep into the current study and shape the maturity of this reflective account. Our research questions were formulated as follow 
a. In what form in the illustrations does gender stereotyping appear?

b. What are the possible impacts of gender bias from a hidden curriculum perspective on learners?

c. What are the possible impacts of gender bias from a hidden curriculum perspective on teachers?

Our objective is to provide empirical evidence and use the findings as a starting point for the description of a set of middle and secondary schools. We will first supply an overview of the supporting literature on gender-equality in an EFL context. Second, we will identify the tacit forms that gender bias could take. Finally, we will attempt to suggest a set of recommendations to improve the quality of the textbook illustrations

\section{Gender Studies in Educational Settings: A theoretical Overview}

An important body of the literature concerning the use of the role of illustrations in school textbooks shows that the importance of this area of study is undeniable.

A lot of research has been carried out on gender issues in education and more specifically in textbooks. However, a widespread lack of gender awareness promotes the ignorance of actors in the field of education with regard gender inequalities and discrimination. Gender bias is therefore, sufficiently important to merit more detailed consideration. This is, then, what the following points will attempt to highlight.

One of the reasons for disenchantment and skepticism with many textbooks in general and ELT in particular, is the way they bind the learners, the parents, the school and the outside world in a very traditional, unquestioned manner that ultimately influences their view of life. In this connection, discriminatory treatment of women is one of the major inadequacies that textbooks suffer from and whose momentum is gaining ground in the educational field.

Research has shown that most textbooks are highly gendered. While the world depicted in them seem to be manmade, one cannot but notice the fact that women are driven to the margin of such instructional materials with little room to express their own thinking and experiences about the world. The idea that women are inferior to men is conveyed through textbooks. Men, on the other hand, are projected as superior and happen to occupy positions of power and leading roles. Minor efforts and personal initiatives, in face of mounting momentum that gender bias is acquiring in the schooling system, can barely move against the mainstream current that prevail in textbooks.

Gender bias has been widely discussed and considerable amounts of data are produced to investigate the misrepresentations and imbalanced power relations between men and women in textbooks. Different researchers concerned themselves with such a thorny area of study, chief among them, Porreca (1984) who conducted a study to evaluate fifteen widely used EFL textbooks $\mathrm{n} m$ She found out that: "Sexism continues to flourish in EFL textbooks. "(Porreca, 1984:718). Her findings revealed a serious degree of females' invisibility in both texts and illustrations. Sunderland (2000) carried out an analytical study whereby she came to the conclusion that the representation of females in textbooks are heavily stereotyped and confine women within domestic and indoor passive activities. According to her, gender bias manifests itself through the over-representation of male characters. Furthermore, men seem to fulfill a strikingly wide range of interesting, creative and prestigious occupational roles unlike women.

Any evaluative study is then a response to some disturbing observations and findings that necessitate a set of objectives to be achieved and actions to be taken with regards to the deficiencies encountered. As far as the purpose of the current research is concerned, textbook evaluation aims to uncover sexism and stereotyping. However, this should in no way releases the teacher too from his responsibility to alert his learners to such a pigeonholing of both sexes.

There is considerable Data that help textbook-writers, instructors and teaching professionals in their evaluative approach with regard to textbooks. Eminent figures whose contributions to the field of ELT textbook's design and analysis have gone a considerable distance, such as Sheldon (1988), and Cunningsworth (1995), all attempted to provide general criteria in order to serve the end of teaching materials' evaluation. According to them, evaluation should encompass matters such as the physical appearance of textbooks, subject content, language, types of activities and skills, and eventually the integration of social and cultural dimensions

As a conclusion, the literature indicated that the abovementioned studies are few examples in the field of textbook studies, but to which the credit goes undoubtedly for raising actors' will in the educational domain to improve the status and image of women in textbooks. Therefore, a wide range of other textbook studies were done for the sole purpose of eliminating gender bias and stimulating change when preparing new editions of textbooks. As the following point will indicate, textbook evaluation studies are of paramount importance Analyzing their contents will not but ensure more chances to correspond to the social changes that occur in the same environment where learners live. 


\section{Illustrations Analysis from a Gender Perspective}

Purposive sampling was implemented in this work. Therefore, out of the four textbooks used for the teaching and learning of English in middle schools, this study is restricted to first year textbook of English. "Spotlight on English" is chosen to be content analyzed and to determine the portrayal of gender roles in the illustrations of this textbook.I employed Levie and Lentz's (1982) categorization of illustrations into representational pictures and nonrepresentational pictures. According to them, the first category of illustrations include: "... ordinary drawings and photographs that show what things look like." (Levie and Lentz, 1982:214) On the other hand, non-representational pictures refer to, for instance, maps and diagrams which "depict the organization and structure of the key concepts of a content area."(Levie and Lentz, 1982:215)

\subsection{Results and Findings}

The first part of this study examines the quantity of the illustrations across the textbook. Such an investigation yielded the following results:

Table 1: Division of the textbook Illustrations

\begin{tabular}{|c|c|c|c|}
\hline $\begin{array}{c}\text { Number of } \\
\text { Pages }\end{array}$ & $\begin{array}{c}\text { Number of pages with } \\
\text { representational illustrations }\end{array}$ & $\begin{array}{c}\text { Number of pages with } \\
\text { nonrepresentational illustrations }\end{array}$ & $\begin{array}{c}\text { Number of pages without } \\
\text { illustrations }\end{array}$ \\
\hline 189 & 87 & 49 & 53 \\
\hline Percentage & $46.03 \%$ & $25.92 \%$ & $28.05 \%$ \\
\hline
\end{tabular}

Results show that the textbook is highly illustrated. Visual inspection of the textbook proved that it has a higher percentage of representational illustrations. However, statistical analysis shows that the difference in the percentage of representational versus nonrepresentational pictures is significant.

It is necessary to know that researchers devised other categories that depended very much on the kind of the material being examined and the aims of the researcher in a given study. For example, Davies 1995 in the commonwealth study on gender bias in school text books' selected: visibility, stereotyping, equal respect, inclusive gender sensitive vocabulary and authority as categories. Other researchers like Obura( 1991) and Sadker and Sadker (1991) have used different but related categories to images, sexism and gender bias in instructional materials. The selected variables I used in the examination of the portrayal of male and female characters are mentioned and discussed below:

a- Frequency of appearance.

b- The portrayal of Reproductive roles (Family roles).

c- The portrayal of productive roles.

d- Depiction of sports activities

Table 2: Appearance Frequency of Illustrated Female and Male Characters in Spotlight on English Textbook.

\begin{tabular}{|l|c|c|c|c|c|}
\hline File & Page & F & M & G & B \\
\hline One & $21-39$ & 04 & 09 & 17 & 24 \\
\hline Percentage & $/$ & $07.40 \%$ & $16.66 \%$ & $31.49 \%$ & $44.45 \%$ \\
\hline Two & $41-59$ & 16 & 35 & 14 & 14 \\
\hline Percentage & $/$ & $20.25 \%$ & $44.31 \%$ & $17.72 \%$ & $17.72 \%$ \\
\hline Three & $61-79$ & 05 & 34 & 00 & 00 \\
\hline Percentage & $/$ & $12.82 \%$ & $87.18 \%$ & $00 \%$ & $00 \%$ \\
\hline Four & $81-100$ & 12 & 15 & 06 & 06 \\
\hline Percentage & $/$ & $30.77 \%$ & $37.47 \%$ & $15.38 \%$ & $15.38 \%$ \\
\hline Five & $101-120$ & 05 & 05 & 02 & 02 \\
\hline Percentage & $/$ & $35.71 \%$ & $35.71 \%$ & $14.29 \%$ & $14.29 \%$ \\
\hline Six & $121-142$ & 24 & 20 & 05 & 00 \\
\hline Percentage & $/$ & $48.98 \%$ & $40.82 \%$ & $10.20 \%$ & $00 \%$ \\
\hline Seven & $143-164$ & 00 & 02 & 17 & 16 \\
\hline Percentage & $/$ & $00 \%$ & $5.71 \%$ & $48.57 \%$ & $45.72 \%$ \\
\hline Total & 309 & 66 & 120 & 61 & 62 \\
\hline
\end{tabular}




\begin{tabular}{|l|c|c|c|c|c|}
\hline Percentage & $100 \%$ & $21.36 \%$ & $38.84 \%$ & $19.74 \%$ & $20.06 \%$ \\
\hline
\end{tabular}

An examination of the results in table 1 that deal with data combined under the heading of the first category, show that there are more illustrated male characters than females in each file. The total number of illustrated males is 120 (38.84\%) compared to $66(21.36 \%)$ for females Therefore; findings portray gender discrimination among characters.

\subsection{Productive Activities}

A close examination of the occupations assigned to male and female characters can be exemplified by data in table 2

Table 2: Illustrated Occupations for Males and Females Characters in the Textbook.

\begin{tabular}{|c|c|c|c|c|}
\hline Page & Type of male occupations & $\mathrm{N}$ of M illustrations & Type of female occupations & $\mathrm{N}$ of $\mathrm{F}$ illustrations \\
\hline 32 & - TV presenter & 2 & 1 & 1 \\
\hline 47 & 1 & 1 & - Top model & 1 \\
\hline 51 & $\begin{array}{l}\text { - Doctor-mechanic-builder-painter-grocer- } \\
\text { photographer-dancer-cameraman }\end{array}$ & 10 & - Teacher & 2 \\
\hline 52 & $\begin{array}{l}\text {-Journalist-dancer-doctor-postman-painter- } \\
\text { actor-singer-comedian-commentator-football } \\
\text { player }\end{array}$ & 10 & $\begin{array}{l}\text { - Dentist } \\
\text { - singer }\end{array}$ & 2 \\
\hline 53 & -Engineer-doctor-taxi-driver-mechanic-painter & 5 & - teacher & 1 \\
\hline 56 & - Santa-Claus & 1 & 1 & 1 \\
\hline 61 & \begin{tabular}{|ll} 
- Running track players & - Base-ball player \\
- Sport-sailing player & - Cycling players \\
\end{tabular} & 14 & $\begin{array}{l}\text { - Field hockey } \\
\text { Players }\end{array}$ & 5 \\
\hline 66 & $\begin{array}{l}\text { - Football-player - Tennis-player } \\
\text { - Box-player - Running track player }\end{array}$ & 5 & I & I \\
\hline 67 & - interviewer & 1 & 1 & 1 \\
\hline 75 & - Soccer player - Horse - racer & 2 & 1 & 1 \\
\hline 81 & - carpenter & 1 & 1 & 1 \\
\hline 84 & - painter & 1 & 1 & 1 \\
\hline 86 & $\begin{array}{l}\text { - Photographer-painter - Taxi-driver } \\
\text { - mechanic }\end{array}$ & 4 & $\begin{array}{l}\text { - Teacher } \\
\text { - Type- writer }\end{array}$ & 2 \\
\hline 89 & - veterinarian & 1 & 1 & 1 \\
\hline 90 & - hunters & 2 & 1 & 1 \\
\hline 91 & 1 & 1 & - teacher & 1 \\
\hline 92 & - worker & 3 & - Air-hostess & 1 \\
\hline 103 & - grocer & 1 & 1 & 1 \\
\hline 106 & 1 & 1 & - TV-presenter & 1 \\
\hline 110 & - doctor & 1 & 1 & 1 \\
\hline 125 & - Receptionist-manager-chief-waiter & 4 & - Guide & 1 \\
\hline 126 & - Manager-waiter & 2 & - Guide & 1 \\
\hline 128 & 1 & 1 & 1 & 1 \\
\hline 129 & - Computer-programmer & 1 & 1 & 1 \\
\hline 131 & 1 & 1 & 1 & 1 \\
\hline 133 & I & I & \begin{tabular}{|l} 
- Guide \\
- Top-model of fashion show
\end{tabular} & 3 \\
\hline 148 & - Weather forecaster & 1 & 1 & 1 \\
\hline 149 & - TV presenter & 1 & 1 & 1 \\
\hline Total & 38 & 66 & 9 & 22 \\
\hline Perc & $80.85 \%$ & $75 \%$ & $19.15 \%$ & $25 \%$ \\
\hline
\end{tabular}

Findings in table 2 show that males have been exposed to 38 (80.85) types of occupations while females have only 9 (19.15) occupations open to them. Looking closely at the portrayal of occupational roles, one notices that they correspond to the society's stereotypical and traditional division of labor. The recurrent illustrations of males as doctors and females as teachers strengthen the already made statement. 


\subsection{Reproductive Activities}

Though not many illustrations have been devoted to the depiction of both or either male and female characters in the domestic dimension, yet, there are all signs that make crystal clear the stereotyped division of the household chores. The following table will enable us to know, if ever a fair share of the family roles has been given to the characters in the illustrations:

Table 3: Male and Female Roles in the Family

\begin{tabular}{|l|c|c|}
\hline Females' Roles & Males' Roles & Page \\
\hline Dropping kids to school & $I$ & 91 \\
\hline Buy food & $I$ & 103 \\
\hline Two female activities & No male activity & $I$ \\
\hline
\end{tabular}

We found that although the family chores are not often visually represented in the textbook illustrations, yet, those that made their appearance in Spotlight on English 1 were entirely assigned to female characters. Obviously, females do not share with the males the same number of domestic responsibilities. The images offered by the textbook-writers are those of females who alone assume the depicted tasks

\subsection{Sport Activities}

It is intended in the fifteenth table to reveal the extent to which females have been portrayed doing sport activities. Gender bias against women is could take place by the under-representation of the females in such a domain or by their omission altogether.

Table 4: Male and Female Characters Illustrated in Sport Activities

\begin{tabular}{|c|c|c|c|c|}
\hline Page & M Illustrations & Sport Activities & F Illustrations & Sport Activities \\
\hline 52 & 2 & $\begin{array}{l}\text {-Football player } \\
\text {-Football commentator }\end{array}$ & l & l \\
\hline 61 & 5 & Running-track, cycling, sport-sailing, soccer. & 1 & Field-hockey \\
\hline 63 & 1 & Football-players & 1 & 1 \\
\hline 66 & 5 & Football-players, tennis-player,box-player, running-track player. & 1 & 1 \\
\hline 71 & 2 & Track-running, athletics & 1 & 1 \\
\hline 75 & 2 & Horse-riding, soccer & 1 & l \\
\hline Total & 17 & 1 & 1 & 1 \\
\hline
\end{tabular}

\section{Discussion}

Although, a small number of illustrations are taken as instances of gender bias, the abovementioned statistics make it crystal clear and speak on the behalf of the remaining ones. Concerning the frequency of appearance of male and female characters, findings show that in all cases, males outnumber the females' illustrated characters in the textbook. As far as the occupational dimension is concerned, those attributed to women are less diverse and inferior to those male productive activities. The occupational roles assigned to women require good looking females. Their productive roles do not necessitate the fact of having pursued any further studies like it is the case for being a top model or a singer. Such sort of images portrays women not only as "more interested in fashion, but also as mannequins, objects to be observed." (Berger, 1972:40) . However, the occupations which require accesses to education are namely a teacher, dentist, and actress. To sum up, the illustrations used in this file were biased against women and portray them in a very narrow way limited to stereotyped occupational roles. Therefore; they maintain the status quo of the unequal division of labor between males and females. As far as the activities concerning the family welfare, findings indicate that women fulfill certain tasks such as taking the kids to school and buying food. Men's participation, on the other hand, is not given much importance and hence not being given an imagistic expression. Furthermore, as the findings concerning the third file could tell, women are far less visible. Sports are taken for granted to be the monopoly of males. other hand, males are represented in about nine kinds of sports including cycling, football, base-ball and track-running, to name only few. . Such a very minor 
representation of females in the physical education sports will without doubt provide girls with a considerable small amount of role models in this orientation

\section{Recommendations}

Promoting equality between the two sexes should be taken into consideration during the process of designing a textbook. Therefore, future textbooks should be sufficiently gender-balanced if we are to realize equality between girl and boy learners. What follows is a set of recommendations to eliminate gender role stereotyping in textbooks:

$>$ Actors in the education field should organize frequent training that target the personnel involved in the production of school instructional materials.

$>$ Not only a gender sensitive knowledge is sufficient, unless teachers are also trained how to discuss and remedy the inadequate representations of the two genders, and especially with regards to females.

$>$ For more visibility, the number of female pictures should increase in the textbook.

$>$ More female characters should be open to a wider range in more diverse productive activities.

\section{Conclusion}

Although Algeria is undergoing changes and developments in all domains including gender, this study revealed that society's old stereotypes are still alive and revived through different, modern and even educational ways. The present research examined only a very few aspects of investigation to determine the representation of both men and women through the textbook representational illustrations. Visibility, Occupational versus domestic dimension, and sport activities, are the variables used in this study. The textbook illustrations were content analyzed so as to spot any form of sexist representations. The results indicate that Gender-biased messages are, among others, one of the side-effects conveyed via such a teaching device. One of the most outrageous manifestations of gender bias is invisibility. Girls and women are almost invisible in the illustrations. According to Sunderland (1994), the issue of invisibility refers to:"when females do not appear as often as males in the text (as well as in the illustrations which serve to reinforce the text), the implicit message is that women's accomplishments, or that they themselves are not important enough to be included." (Porreca, 1984:706)

In addition to that, textbook-writers did not fail to portray women in traditional roles. While, it reflects men doing a variety of adventurous, interesting, and skillful job, women are confined to a set of very restricted social activities. Males' dominance in the occupational dimension may hold back the girls' and prevent them from venturing into non-traditional occupations.

\section{References}

Berger, J.1972, Way of Seeing, London: Penguin

Cunningsworth, A, 1984 Evaluating and Selecting EFL Teaching Materials, Heinemann.

Davies, B., 1995, Gender Bias in School Textbooks, London: Commonwealth Secretariat

Obura, A, P, 1991, Changing Image: Portrayal of Girls and Women in Kenyan Textbooks, Nairobi: ACTS

Porreca, K.L., 1984, Sexism in Current ESL Textbooks. TESOL Quarterly,18,704-724.

Sadker, MP. And SADKER,D.1991.The Issues of Gender in Elementary and Secondary Education, Review of Research in Education,17. Sheldon, E, L,1988, Evaluating ELT Textbooks and Materials in ELT, Journal Volume42/4 October, Oxford University Press.

Sunderland, J.2000, New Understanding of Gender and Language Classroom Research: texts, teacher and student talk, language Teaching Research,4,149-173 